\title{
Pengaruh Tingkat Keasaman pada Karakteristik Zeolit Alam sebagai Adsorben Ammonium Hidroksida $\left(\mathrm{NH}_{4} \mathrm{OH}\right)$
}

\author{
Nur Indah Fajar Mukti' ${ }^{*}$ Luthfia Maula Hanifah, Zonanda Rizki Haromain, Alfian Dama Arrazi, Alfian Nuraya
}

Jurusan Teknik Kimia, Universitas Islam Indonesia

Jalan Kaliurang km 14,5 Yogyakarta 55584, Indonesia

\section{Artikel histori :}

Diterima Mei 2017

Diterima dalam revisi Juli 2017

Diterima Agustus 2017

Online September 2017

\begin{abstract}
ABSTRAK: Zeolit alam merupakan jenis batuan mineral yang banyak tersedia di Indonesia. Di antara banyak manfaat lainnya, zeolit alam dapat digunakan sebagai adsorben untuk mengatasi pencemaran akibat limbah cair berupa senyawa - senyawa ammonia dan kombinasi turunannya. Penelitian ini dimaksudkan untuk mempelajari pengaruh perbedaan tingkat keasaman terhadap karakteristik zeolit alam sebagai adsorben ammonium hidroksida $(\mathrm{NH} 4 \mathrm{OH})$. Efek penambahan asam pada zeolit alam dipelajari dengan memvariasikan konsentrasi $\mathrm{H} 2 \mathrm{SO} 4(0,5 \mathrm{~N} ; 3 \mathrm{~N}$ and $5 \mathrm{~N})$ dan $\mathrm{H} 3 \mathrm{PO} 4(0,5 \mathrm{~N} ; 3 \mathrm{~N}$ and $5 \mathrm{~N})$ yang digunakan dalam proses pengasaman dan dealuminasi. Pada penelitian ini permukaan zeolit diamati menggunakan analisis fourier transform infrared (FTIR). Hasil penelitian menunjukkan bahwa dengan konsentrasi yang sama, tingkat dealuminasi pada zeolit alam dengan menggunakan asam kuat (H2SO4) lebih tinggi dibandingkan dengan menggunakan asam lemah (H3PO4). Selain itu, diketahui pula jumlah $\mathrm{NH} 4 \mathrm{OH}$ yang terjerap pada H-Zeolite-H2SO4 memiliki kapasitas penjerapan $\mathrm{NH} 4 \mathrm{OH}$ yang lebih tinggi dibandingkan dengan $\mathrm{H}$-Zeolite-H3PO4. Kapasitas adsorpsi NH4OH untuk H-Zeolite-H2SO4 dan H-Zeolite-H3PO4 secara berturutturut adalah 23,6 mg/g dan 12,9 mg/g. Dari analisis FTIR yang dilakukan, adsorpsi amonium hidroksida pada zeolit terdealuminasi terjadi pada puncak gugus $\mathrm{OH}$ Brønsted.
\end{abstract}

Kata Kunci: adsorpsi, ammonium hiroksida, asam sulfat, asam fosfat, dealuminasi,

ABSTRACT: Natural zeolites are minerals that are widely available in Indonesia. Among many other benefits, the natural zeolite can be used as an adsorbent to reduce water pollutant caused by ammonia compounds and combination of derivatives. This research aimed to study the effect of different acids on zeolite characterizatics as adsorbent of ammonium hydroxide $(\mathrm{NH} 4 \mathrm{OH})$. The effect of acids addition on natural zeolite was studied by varying the concentration of $\mathrm{H} 2 \mathrm{SO} 4(0,5 \mathrm{~N} ; 3 \mathrm{~N}$ and $5 \mathrm{~N})$ and $\mathrm{H} 3 \mathrm{PO} 4(0,5 \mathrm{~N} ; 3 \mathrm{~N}$ and $5 \mathrm{~N})$. In this study, zeolite surface was observed by Fourier Transform Infrared (FTIR). Results showed that the amount of $\mathrm{NH} 4 \mathrm{OH}$ adsorbed on $\mathrm{H}$ - zeolite has a maximum $(23,6 \mathrm{mg} / \mathrm{gram}$ zeolit) at $5 \mathrm{~N}$ $\mathrm{H} 2 \mathrm{SO} 4$. From the $\mathrm{NH} 4 \mathrm{OH}$ uptake experiment, it was noted that zeolite obtained from $\mathrm{H}-$ Zeolite-H2SO4 has higher $\mathrm{NH} 4 \mathrm{OH}$ adsorption capacity than that of zeolite obtained from $\mathrm{H}-$ Zeolite-H3PO4. The adsorption capacity of H-Zeolite-H2SO4, H-Zeolite-H3PO4, are 23,6 $\mathrm{mg} / \mathrm{g}$ and $12,9 \mathrm{mg} / \mathrm{g}$, respectively. FTIR analysis was showed that $\mathrm{NH} 4 \mathrm{OH}$ adsorbed on the surface of $\mathrm{H}$ - zeolite on Brønsted acid peak.

Keywords: adsorption, ammonium hydroxide, sulfuric acid, phosphoric acid, dealumination, FTIR

\section{Pendahuluan}

Indonesia merupakan Negara yang memiliki berbagai macam jenis batuan mineral alam yang sangat bervariasi. Salah satu batuan alam yang saat ini mulai banyak dimanfaatkan adalah zeolite. Semakin banyaknya penelitian dan pemanfaatan terhadap zeolite dikarenakan zeolite memiliki banyak keistimewaan yaitu sifatnya yang dapat diatur sehingga dapat dimodifikasi sesuai dengan kebutuhan dengan cara pemanasan atau proses kimia. Zeolit memiliki banyak kegunaan, diantaranya sebagai katalis, adsorben, penukar ion, dan penghilangan kesadahan pada air.

Pada umumnya zeolit yang diperoleh dari alam mempunyai jenis dan komposisi yang beraneka ragam tergantung pada lokasinya. Selain itu, zeolite yang diperoleh dari alam banyak mengandung pengotor dan

\footnotetext{
* Corresponding Author:

Email: Email: nurindah_fm@uii.ac.id
} 
umumnya tidak cukup aktif untuk digunakan sebagai katalis atau bahan penjerap. Oleh karena itu, diperlukan perlakuan terlebih dahulu agar dapat digunakan sebagai adsorben maupun katalis. Dalam kegunaannya sebagai adsorben, permukaan zeolite dapat dimodifikasi sesuai dengan adsorbat yang akan dijerap.

Salah satu kegunaan zeolite sebagai adsorben adalah untuk mengatasi limbah cair yang disebabkan oleh senyawa-senyawa ammonia dan kombinasi turunannya. Hal ini disebabkan struktur zeolit yang sangat porous serta memiliki kation-kation yang dapat dipertukarkan dapat dimanfaatkan untuk menjerap limbah industri (Saltali et al, 2007). Limbah ammonia memerlukan perlakuan khusus dikarenakan beberapa senyawa turunan amonia-organik tertentu yang sangat beracun bagi biota akuitik pada kadar ratusan kali lipat lebih kecil dari kadar amonia bebas dalam limbah cair. Selain itu, menurut Keputusan Menteri Negara Lingkungan Hidup Tahun 1995 batas maksimum persyaratan amonia bebas dalam air minum yaitu kurang dari 0,05 ppm. Oleh karena itu, diperlukan penelitian lebih lanjut untuk mengatasi masalah limbah cair ammonia ini yang salah satunya dapat dilakukan melalui proses adsorpsi.

Sifat adsorpsi zeolit terjadi karena terdapatnya rongga dalam struktur zeolit. Kapasitas penjerapan zeolit berhubungan dengan ruang dan volume yang ada. Beberapa penelitian mengenai modifikasi permukaan zeolit alam sebagai adsorben ammonia telah banyak dilakukan. Veselovskaya et al. (2012) melakukan modifikasi zeolit menggunakan $\mathrm{BaCl} 2$ untuk menjerap larutan ammonia. Lin et al. (2013) menyimpulkan bahwa modifikasi zeolit menggunakan $\mathrm{NaCl}$ mampu meningkatkan penjerapan ammonia seiring dengan meningkatnya jumlah $\mathrm{Na}$ pada permukaan zeolit. Modifikasi zeolit menggunakan $\mathrm{NaCl}$ juga telah dilakukan oleh Ding dan Sartaj (2015). Dari penelitiannya zeolit yang telah dimodifikasi menggunakan $\mathrm{NaCl}$ mampu menjerap ammonia sebanyak $22,9 \mathrm{mg} / \mathrm{g}$.

Pada penelitian ini dipelajari pengaruh tingkat keasaman terhadap tingkat dealuminasi zeolit alam dan pengaruhnya terhadap penjerapan $\mathrm{NH} 4 \mathrm{OH}$. Dalam hal ini analisis dengan fourier transform infrared digunakan untuk mengidentifikasi gugus $\mathrm{NH} 4 \mathrm{OH}$ atau ammonia yang terjerap pada permukaan zeolit pada tingkatan dealuminasi yang berbeda. Variabel yang diteliti adalah pengaruh penambahan $\mathrm{H} 3 \mathrm{PO} 4$ dan $\mathrm{H} 2 \mathrm{SO} 4$ dalam proses dealuminasi serta pengaruhnya terhadap banyaknya $\mathrm{NH} 4 \mathrm{OH}$ yang terjerap oleh zeolit.

\section{Metode Penelitian}

Bahan-bahan yang digunakan dalam penelitian ini adalah zeolit alam yang didapatkan dari Gunung Kidul. Sedangkan larutan asam sulfat $98 \%$ dari Merck, larutan asam fosfat $85 \%$ dari Merck, larutan $\mathrm{HCl} 37 \%$ dari Merck dan larutan ammonia $25 \%$ dari Merck. Prosedur pelaksanaan yang digunakan dalam penelitian ini meliputi:

\subsection{Persiapan bahan}

Zeolit alam yang berupa bongkahan besar dihancurkan dan lalu dihaluskan dengan ball mill untuk kemudian diayak hingga diperoleh ukuran $-100+200$ mesh. Kemudian zeolit dicuci menggunakan aquadest pada suhu $100^{\circ} \mathrm{C}$ selama 1 jam sebanyak 3 kali. Zeolit kemudian dikeringkan pada suhu $120^{\circ} \mathrm{C}$ selama 8 jam.

\subsection{Pengasaman dan dealuminasi}

Zeolit yang telah dicuci kemudian diasamkan menggunakan H3PO4 pada suhu 80oC selama 1 jam sebanyak 3 kali. Proses pengasaman terhadap zeolit dengan H3PO4 dilakukan pada berbagai konsentrasi $(0,5 \mathrm{~N}, 3 \mathrm{~N}$ dan $5 \mathrm{~N}$ ). Kemudian dilakukan kembali pencucian dengan aquadest pada suhu $80 \mathrm{oC}$ sampai $\mathrm{pH}$ larutan 3. Zeolit kemudian dikeringkan pada suhu $120 \mathrm{oC}$ selama 8 jam. Pada proses ini selain terjadi pertukaran kation juga terjadi proses dealuminasi zeolit. Dengan langkah yang sama juga dilakukan untuk proses pengasaman terhadap zeolit dengan $\mathrm{H} 2 \mathrm{SO} 4$ pada berbagai konsentrasi $(0,5 \mathrm{~N}, 3 \mathrm{~N}$ dan $5 \mathrm{~N})$. Adsorpsi ammonia

\subsection{Adsorpsi ammonia}

H-zeolit dimasukkan dalam larutan $\mathrm{NH}_{4} \mathrm{OH}$ 0,1 N. Waktu adsorpsi dihitung sejak sampel dimasukkan dalam larutan (waktu $\mathrm{t}=0$ ). Untuk periode waktu tertentu sampel diambil sebanyak $2 \mathrm{~mL}$. Analisis sampel dilakukan dengan metoda titrasi menggunakan $\mathrm{HCl}$ 0,01 N yang telah distandardisasi dengan menggunakan boraks. Proses adsorpsi ini dikenakan untuk sampel $\mathrm{H}$-zeolit yang diasamkan dalam $\mathrm{H}_{3} \mathrm{PO}_{4} 5 \mathrm{~N}$, H-zeolit yang telah diasamkan dengan $\mathrm{H}_{2} \mathrm{SO}_{4}$ $3 \mathrm{~N}$ dan zeolit yang hanya dicuci dengan menggunakan aquades. Pada bagian akhir proses adsorpsi, zeolit tersebut kemudian direndam semalaman (22 jam) dan kemudian dikeringkan dengan menggunakan oven pada suhu $150^{\circ} \mathrm{C}$ selama 8 jam.

Selanjutnya, konsentrasi $\mathrm{NH}_{4} \mathrm{OH}$ di dalam padatan dapat ditentukan dari data percobaan dengan membuat neraca massa $\mathrm{NH} 4 \mathrm{OH}$ di dalam cairan dan padatan. Konsentrasi $\mathrm{NH} 4 \mathrm{OH}$ pada padatan pada keadaan setimbang (Pers. 1)

$$
x_{e}=\frac{(C o-C e) V}{W}
$$

\subsection{Analisis dengan FTIR}

Sampel zeolit dihaluskan dengan mortal sampai halus. Kemudian 0,001 gram sampel zeolit yang telah dihaluskan dicampur dengan $\mathrm{KBr}$ sampai mencapai berat 0,02 gram. Setelah homogen, campuran tersebut diambil sebanyak 0,004 gram dan kemudian dicampur dengan $\mathrm{KBr}$ sampai mencapai berat 0,02 gram. Setelah homogen campuran ditimbang sebanyak 0,01 gram. Campuran kemudian dicetak dengan menggunakan alat cetak sampel yang tersedia sedemikian sehingga diperoleh tingkat transparansi tertentu. Sampel yang sudah siap kemudian diletakkan pada tempat sampel di dalam ruang FTIR yang tersedia. Hasil pengukuran dalam persen transmitan direkam secara otomatis pada personal computer. 


\subsection{Analisis data}

Keadaan kesetimbangan adsorpsi pada penelitian ini dievaluasi dengan persamaan - persamaan empiris adsorption isotherm:

Langmuir isotherm (Perry and Green, 1997)

$$
x_{e}=\frac{K \cdot b \cdot C e}{1+K \cdot C e}
$$

Freundlich isotherm (Perry and Green, 1997)

$$
x_{e}=K \cdot C e^{1 / n}
$$

\section{Hasil dan Pembahasan}

Zeolit alam pada awalnya tidak aktif perlu diaktifkan terlebih dahulu. Pengaktifan zeolit dilakukan dengan dua tahap yaitu tahap pencucian zeolit menggunakan aquadest yang bertujuan untuk membersihkan zeolit yang masih mengandung pengotor yang dapat larut dalam air dan untuk membuka pori-porinya.

Tabel 1. Komposisi Zeolit dari Gunungkidul

\begin{tabular}{ll}
\hline Komponen & Berat $(\%)$ \\
\hline $\mathrm{SiO}_{2}$ & 69,50 \\
$\mathrm{TiO}_{2}$ & 0,14 \\
$\mathrm{Al}_{2} \mathrm{O}_{3}$ & 12,00 \\
$\mathrm{Fe}_{2} \mathrm{O}_{3}$ & 0,93 \\
$\mathrm{CaO}$ & 0,31 \\
$\mathrm{MgO}$ & 0,86 \\
$\mathrm{~K}_{2} \mathrm{O}$ & 0,66 \\
$\mathrm{Na}_{2} \mathrm{O}$ & 2,22 \\
$\mathrm{MnO}$ & 0,01 \\
$\mathrm{P}_{2} \mathrm{O}$ & 0,05 \\
$\mathrm{H}_{2} \mathrm{O}$ & 4,07 \\
$\mathrm{HD}$ & 9,11 \\
\hline
\end{tabular}

Selanjutnya dilakukan pengasaman pada zeolit dengan menggunakan berbagai jenis asam $\left(\mathrm{HNO}_{3}, \mathrm{H}_{2} \mathrm{SO}_{4}, \mathrm{H}_{3} \mathrm{PO}_{4}\right)$. Pengasaman ini bertujuan untuk menukar kation yang ada dalam zeolit digantikan dengan proton $\mathrm{H}+$ dari asam, selain itu juga terjadi proses dealuminasi. Zeolit dapat dipertukarkan kationnya karena perbedaan muatan antara $\mathrm{Si}^{4+}$ dan $\mathrm{Al}^{3+}$ menjadikan $\mathrm{Al}$ dalam kristal bermuatan negatif dan membutuhkan kation penetral. Kation penetral yang bukan menjadi bagian dari kerangka ini mudah diganti dengan kation lainnya. Penggantian kation penetral dengan proton menjadikan zeolit menjadi padatan yang bersifat asam.

Tahap pencucian zeolit dilakukan sampai $\mathrm{pH}$ larutan mencapai 3. Hal ini dikarenakan proses adsorpsi akan lebih efektif dilakukan pada $\mathrm{pH}$ 4-8. Karena pada range $\mathrm{pH}$ tersebut efisiensi penjerapan ammonium hidroksida pada permukaan zeolit akan meningkat dan akan mulai turun kembali pada pH 9 (Saltali et al., 2006). Selain itu, jika terdapat asam yang tertinggal maka asam tersebut dapat bereaksi dengan $\mathrm{NH} 4 \mathrm{OH}$ yang dapat mempengaruhi deteksi penjerapan.

\subsection{Karakteristik zeolit alam Gunung Kidul}

Komposisi dari zeolit alam yang digunakan disajikan pada Tabel 1. Berdasarkan hasil analisis menggunakan Energy Diffraction X-Ray (EDX), zeolit alam yang berasal dari Gunungkidul merupakan jenis zeolit mordernite. Zeolit mordernite adalah jenis zeolite yang memiliki rasio $\mathrm{Si} / \mathrm{Al}$ sebesar 5,5 - 6,2. Sebagaimana terlihat pada Tabel 1., terlihat bahwa kandungan Si dan Al pada zeolite alam dari Gunungkidul secara berturut-turut adalah 69,50\% dan $12,00 \%$. Sehingga rasio dari Si dan Al dari zeolite alam Gunungkidul sebesar 5,79.

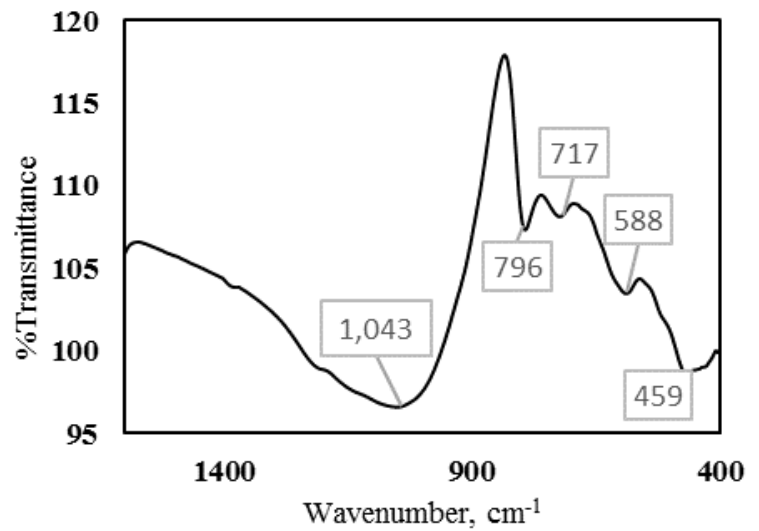

Gambar 1. Hasil spektrum FTIR zeolit alam Gunungkidul

Hasil tersebut juga diperkuat dengan data hasil analisis menggunakan Fourier Transform Infrared (FTIR). Pembacaan spektra FTIR terhadap sampel zeolit alam dari Gunungkidul yang digunakan dalam penelitian ini dapat dilihat pada Gambar 1. Dari analisis FTIR vibrasi framework zeolit (stretching and bending) dapat terlihat pada daerah mid-IR dan far-IR. Untuk asymmetrical stretching mode $(\longleftarrow$ OTO $\rightarrow$ ) terletak pada $1250-950 \mathrm{~cm}$ 1 , symmetrical stretching $(\leftarrow \mathrm{OTO} \rightarrow$ ) terletak pada $790-$ $650 \mathrm{~cm}-1$, sedangkan untuk T-O bending mode terletak pada $500-420 \mathrm{~cm}-1$. Sedangkan untuk group $\mathrm{OH}$ pada zeolit terlihat pada daerah 3600-3650 cm-1, (Auerbach, S., 2003).

Tabel 2. Data IR untuk Mordernite

\begin{tabular}{lllllll}
\hline \multirow{2}{*}{ Tipe zeolite } & \multicolumn{2}{l}{$\begin{array}{l}\text { Asymmetrical } \\
\text { stretch }\end{array}$} & $\begin{array}{l}\text { Symmetrical } \\
\text { stretch }\end{array}$ & $\begin{array}{l}\text { Double } \\
\text { Ring }\end{array}$ & $\begin{array}{l}\mathrm{T}-\mathrm{O} \\
\text { bend }\end{array}$ \\
\cline { 2 - 5 } & $E$ & $I$ & $E$ & $I$ & & \\
\hline Mordernite & 1223 & 1045 & 800 & 720 & 580,560 & 450 \\
\hline
\end{tabular}

Dengan membandingkan spektra hasil pengukuran pada Gambar 1 dan vibrasi gugus-gugus untuk zeolit mordernite pada Tabel 2 dapat disimpulkan bahwa zeolit yang berasal dari Gunungkidul merupakan zeolit jenis mordernite. 


\subsection{Pengaruh pengasaman terhadap tingkat dealuminasi}

Penambahan Asam pada zeolit menyebabkan zeolit mengalami proses dealuminasi. Dealuminasi terjadi karena Al dalam kerangka zeolit larut dan bereaksi dengan asam. Efek dealuminasi akan menyebabkan rasio $\mathrm{Si} / \mathrm{Al}$ dalam zeolit meningkat. Asam yang ditambahkan pada proses pertukaran kation menyumbang proton sebagai asam Brønsted pada zeolit, sehingga semakin tinggi konsentrasi asam maka semakin kuat keasaman zeolit. Namun konsentrasi asam yang semakin kuat akan menyebabkan rasio $\mathrm{Si} / \mathrm{Al}$ semakin besar sehingga jumlah asam yang ada pada zeolit semakin sedikit (Wang et al.,2007).

Zeolit yang telah melalui proses pengasaman selanjutnya dilakukan analisis menggunakan FTIR untuk mengetahui perubahan struktur dari zeolit setelah proses pengasaman tersebut. Hasil analisis FTIR untuk masingmasing zeolit dapat dilihat pada Gambar 2.

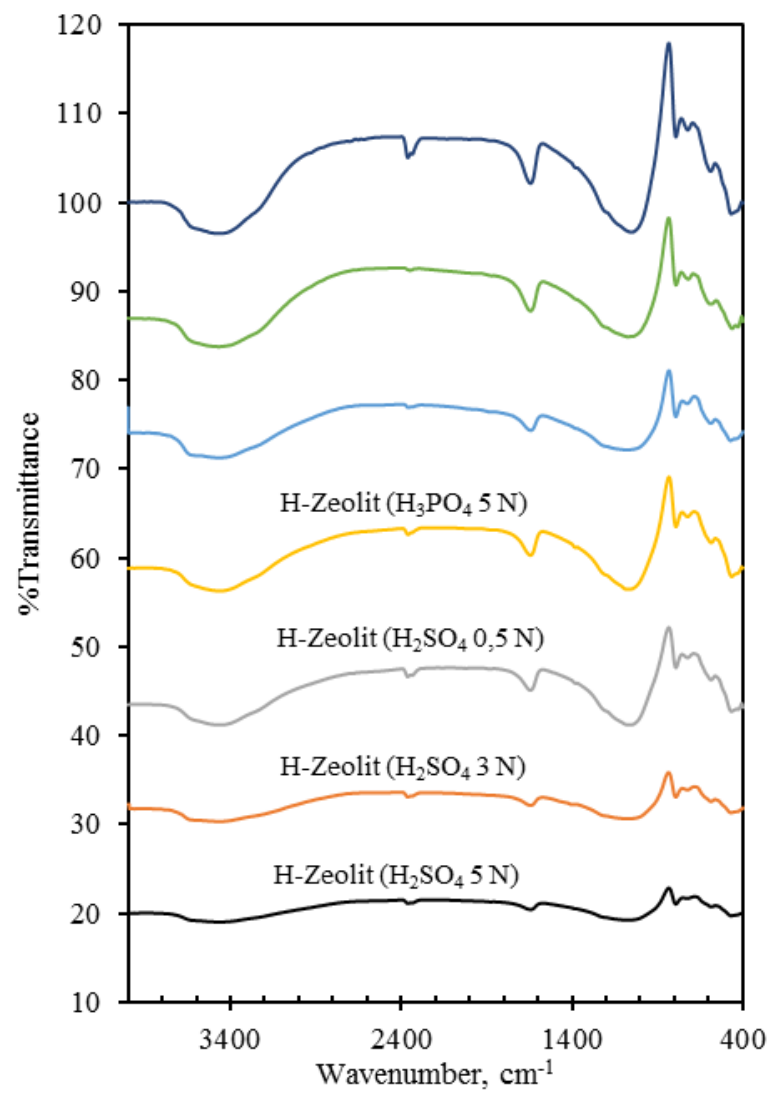

Gambar 2. Hasil analisis FTIR pada zeolit sebelum dan setelah pengasaman

Dari Gambar 2 terlihat adanya perubahan struktur pada zeolit alam yang telah mengalami proses pengasaman. Perbedaan terlihat pada daerah serapan antara 3500-3300 $\mathrm{cm}^{-1}, 2400 \mathrm{~cm}^{-1}, 1800-1600 \mathrm{~cm}^{-1}, 1200-900 \mathrm{~cm}^{-1}$. Pada daerah $3500-3300 \mathrm{~cm}^{-1}, 1800-1600 \mathrm{~cm}^{-1}, 1200-900 \mathrm{~cm}^{-1}$ mengalami penurunan puncak serapan seiring dengan meningkatnya konsentrasi dari $\mathrm{H}_{3} \mathrm{PO}_{4}$ meskipun penurunannya tidak cukup signifikan. Hal yang sama ditunjukkan pula oleh zeolit yang telah mengalami pengasaman oleh $\mathrm{H}_{2} \mathrm{SO}_{4}$. Dimana pada daerah tersebut telah mengalami penurunan puncak serapan pada daerah tersebut dan berkurangnya puncak serapan pada daerah tersebut cukup signifikan dibandingkan dengan penambahan $\mathrm{H}_{3} \mathrm{PO}_{4}$. Sedangkan untuk puncak serapan 2400 $\mathrm{cm}^{-1}$, zeolit dengan penambahan $\mathrm{H}_{3} \mathrm{PO}_{4}$ memberikan hasil yang berbeda dengan zeolit dengan penambahan $\mathrm{H}_{2} \mathrm{SO}_{4}$. Dengan penambahan $\mathrm{H}_{3} \mathrm{PO}_{4}$ pada zeolit alam puncak serapan pada daerah tersebut menghilang meskipun hanya dengan penambahan konsentrasi $\mathrm{H}_{3} \mathrm{PO}_{4}$ yang rendah. Namun dengan penambahan $\mathrm{H}_{2} \mathrm{SO}_{4}$ pada zeolit alam masih terlihat adanya puncak serapan pada daerah tersebut meskipun terjadi penurunan puncak serapan.

Dari hasil analisis FTIR pada Gambar 2 tersebut dapat diprediksi adanya kerusakan struktur pada zeolit alam dengan penambahan $\mathrm{H}_{2} \mathrm{SO}_{4}$ konsentrasi tinggi $\left(\mathrm{H}_{2} \mathrm{SO}_{4} 5 \mathrm{~N}\right)$. Sedangkan pada zeolit alam dengan penambahan konsentrasi $\mathrm{H}_{3} \mathrm{PO}_{4}$ yang sama $(5 \mathrm{~N})$ tidak memperlihatkan hal yang sama. Hal ini disebabkan karena perbedaan tingkat keasaman dari $\mathrm{H}_{3} \mathrm{PO}_{4}$ dan $\mathrm{H}_{2} \mathrm{SO}_{4} \cdot \mathrm{H}_{2} \mathrm{SO}_{4}$ merupakan asam kuat, sedangkan $\mathrm{H}_{3} \mathrm{PO}_{4}$ merupakan golongan asam lemah. Sehingga dengan penambahan konsentrasi $\mathrm{H}_{2} \mathrm{SO}_{4}$ yang terlalu besar dapat merusak struktur dari zeolit alam tersebut. Namun kerusakan struktur tidak diperlihatkan pada penambahan konsentrasi $\mathrm{H}_{3} \mathrm{PO}_{4}$ yang tinggi. Untuk itu, pada proses penjerapan ammonium hidroksida digunakan $\mathrm{H}$-zeolit dari $\mathrm{H}_{3} \mathrm{PO}_{4} 5 \mathrm{~N}$ dan H-zeolit dari $\mathrm{H}_{2} \mathrm{SO}_{4} 3 \mathrm{~N}$.

\subsection{Adsorpsi Ammonium Hidroksida}

a)

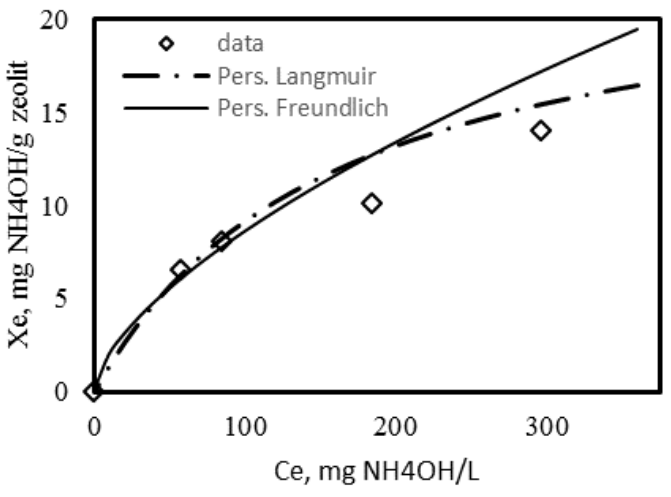

b)

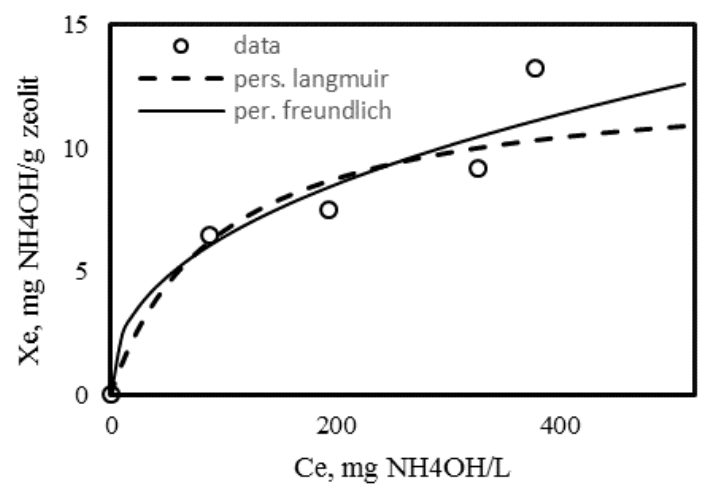

Gambar 3. Kestimbangan adsorpsi $\mathrm{NH} 4 \mathrm{OH}$ pada $\mathrm{H}-\mathrm{Zeolit}$ 
(a) H- Zeolit H2SO4, (b) H-Zeolit H3PO4

Proses adsorpsi dilakukan setelah zeolit telah mengalami pengaktifan. Penelitian ini dilakukan dengan menggunakan proses batch dengan melihat pengaruh penambahan waktu terhadap $\mathrm{NH}_{4} \mathrm{OH}$ yang terjerap pada permukaan zeolit. Dari proses adsorpsi pada permukaan zeolit diperoleh hubungan kesetimbangan antara konsentrasi $\mathrm{NH}_{4} \mathrm{OH}$ di cairan dengan konsentrasi $\mathrm{NH} 4 \mathrm{OH}$ di padatan.

Tabel 3. Nilai Konstanta untuk Persamaan Langmuir dan Persamaan Freundlich

\begin{tabular}{lcll}
\hline \multicolumn{2}{l}{ Persamaan Langmuir } & \multicolumn{2}{l}{ Persamaan Freundlich } \\
\hline \multicolumn{2}{l}{ H-Zeolit $\mathbf{H}_{2} \mathbf{S O}_{\mathbf{4}} \mathbf{3} \mathbf{~ N}$} & & \\
$\mathrm{K}(\mathrm{L} / \mathrm{mg})$ & $6,336 \times 10^{-3}$ & $\mathrm{k}$ & 0,460 \\
$\mathrm{~b}(\mathrm{mg} / \mathrm{gr})$ & 23,616 & $\mathrm{n}$ & 1,571 \\
H-Zeolit $\mathbf{H}_{\mathbf{3}} \mathbf{P O}_{\mathbf{4}} \mathbf{5 N}$ & & \\
$\mathrm{K}(\mathrm{L} / \mathrm{mg})$ & $1,051 \times 10^{-2}$ & $\mathrm{k}$ & 0,934 \\
$\mathrm{~b}(\mathrm{mg} / \mathrm{gr})$ & 12,928 & $\mathrm{n}$ & 2,398 \\
\hline
\end{tabular}

Dilakukan pula analisis FTIR untuk H-Zeolit sebelum dan sesudah proses adsorspsi. Dari hasil analisis FTIR diperoleh data seperti pada Gambar 4. Dari Gambar 4 terlihat bahwa terdapat perbedaan antara zeolit yang sebelum proses adsorpsi dan setelah proses adsorpsi.

a)

b)
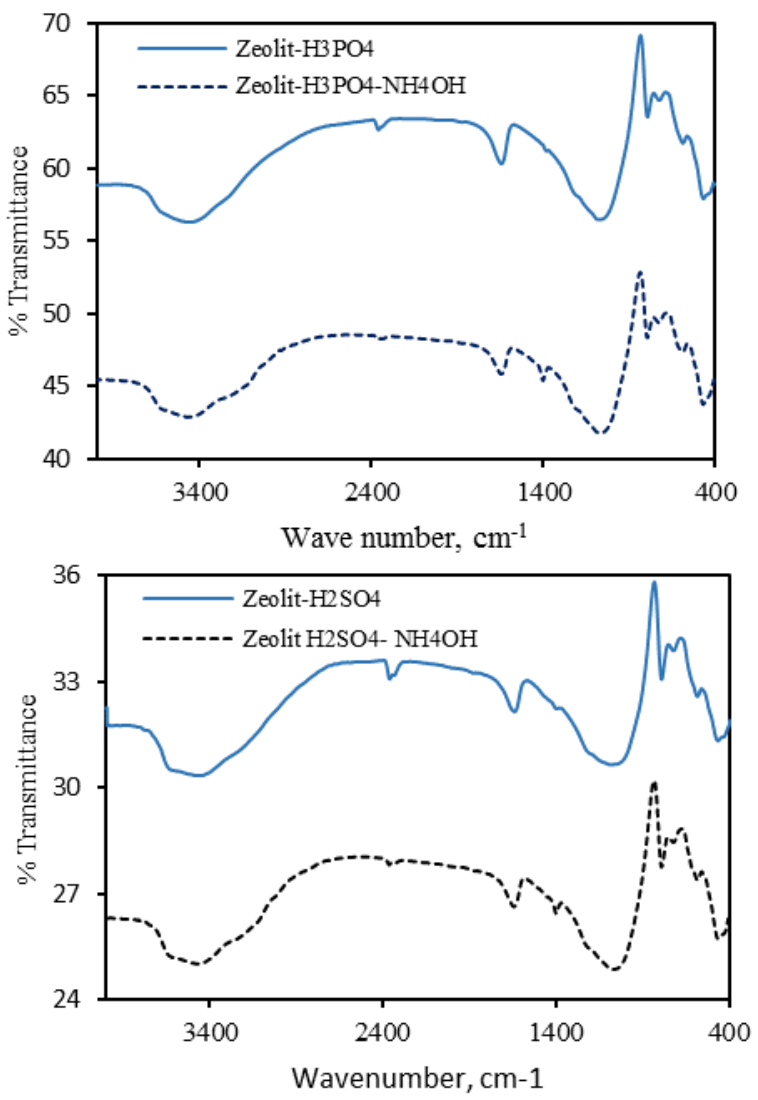

Gambar 4. Hasil analisis FTIR pada zeolit sebelum dan setelah adsorpsi $\mathrm{NH}_{4} \mathrm{OH}$. (a) $\mathrm{H}-Z$ eolit-H3PO4 (b) H-Zeolit$\mathrm{H} 2 \mathrm{SO} 4$
Pada zeolit setelah proses adsorpsi terlihat adanya peak baru pada kisaran 3200 - 3300 dan $1350-1450 \mathrm{~cm}^{-1}$. Selain itu, terlihat pula adanya kehilangan/pengurangan peak pada kisaran $2400 \mathrm{~cm}^{-1}$. Dari hasil analisis FTIR stretching vibrations ion ammonium pada zeolit terlihat pada $3300 \mathrm{~cm}^{-1}$ dan pada $1450 \mathrm{~cm}^{-1}$ untuk ikatan $\mathrm{NH}$, (Auerbach et al., 2003).

Gambar 3 menunjukkan bahwa hubungan kesetimbangan antara konsentrasi $\mathrm{NH} 4 \mathrm{OH}$ dalam padatan dengan konsentrasi $\mathrm{NH}_{4} \mathrm{OH}$ dalam cairan untuk $\mathrm{H}$-zeolit- $\mathrm{H}_{3} \mathrm{PO}_{4}$ dan $\mathrm{H}$-zeolit- $\mathrm{H}_{2} \mathrm{SO}_{4}$. Dari Gambar 3 terlihat bahwa data kesetimbangan hasil percobaan yang dilakukan mendekati Persamaan Freundlich. Nilai - nilai konstanta pada Persamaan Langmuir dan Persamaan Freundlich dapat terlihat pada Tabel 3.

Dari Gambar 3 terlihat bahwa H-Zeolit- $\mathrm{H}_{2} \mathrm{SO}_{4}$ memiliki kapasitas penjerapan $\mathrm{NH}_{4} \mathrm{OH}$ yang lebih tinggi dibandingkan dengan $\mathrm{H}-\mathrm{Z}$ eolit- $\mathrm{H}_{3} \mathrm{PO}_{4}$. Dari nilai-nilai konstanta pada persamaan Langmuir yang diperoleh pada Tabel 3 juga terlihat bahwa kapasitas maksimum dari $\mathrm{H}-$ Zeolit- $\mathrm{H}_{2} \mathrm{SO}_{4}$ lebih tinggi dibandingkan dengan $\mathrm{H}$-Zeolit$\mathrm{H}_{3} \mathrm{PO}_{4}$. Nilai kapasitas maksimum untuk $\mathrm{H}-\mathrm{Zeolit}-\mathrm{H}_{2} \mathrm{SO}_{4}$ dan $\mathrm{H}$-Zeolit- $\mathrm{H}_{3} \mathrm{PO}_{4}$ secara berturut-turut yaitu 23,616 $\mathrm{mg} /$ gram zeolit dan $12,928 \mathrm{mg} /$ gram zeolit.

\section{Kesimpulan}

Dari penelitian yang dilakukan, tingkat dealuminasi akan meningkat seiring dengan meningkatnya konsentrasi asam yang digunakan. Dengan konsentrasi yang sama, tingkat dealuminasi dengan menggunakan asam kuat $\left(\mathrm{H}_{2} \mathrm{SO}_{4}\right)$ lebih tinggi dibandingkan dengan menggunakan asam lemah $\left(\mathrm{H}_{3} \mathrm{PO}_{4}\right)$. Selain itu, hasil penelitian ini juga menunjukkan bahwa jumlah $\mathrm{NH}_{4} \mathrm{OH}$ yang terjerap pada H-Zeolite$\mathrm{H}_{2} \mathrm{SO}_{4}$ memiliki kapasitas penjerapan $\mathrm{NH}_{4} \mathrm{OH}$ yang lebih tinggi dibandingkan dengan $\mathrm{H}-Z$ eolite- $\mathrm{H}_{3} \mathrm{PO}_{4}$. Kapasitas adsorpsi $\mathrm{NH}_{4} \mathrm{OH}$ untuk $\mathrm{H}$-Zeolite- $\mathrm{H}_{2} \mathrm{SO}_{4}$ dan $\mathrm{H}$-Zeolite$\mathrm{H}_{3} \mathrm{PO}_{4}$ secara berturut-turut adalah $23,6 \mathrm{mg} / \mathrm{g}$ dan 12,9 $\mathrm{mg} / \mathrm{g}$. Dari analisis FTIR yang dilakukan, adsorpsi amonium hidroksida pada zeolit terdealuminasi terjadi pada puncak gugus $\mathrm{OH}$ Brønsted.

\section{Ucapan terimakasih}

Penulis mengucapkan terima kasih sebesar-besarnya kepada Jurusan Teknik Kima Universitas Islam Indonesia yang telah mendanai penelitian ini melalui skema penelitian Dosen dan Mahasiswa.

\section{Daftar lambang}

$\mathrm{b}=$ konstanta persamaan Langmuir

$\mathrm{Ce}=$ konsentrasi $\mathrm{NH}_{4} \mathrm{OH}$ dalam cairan pada saat kesetimbangan $(\mathrm{mg} / \mathrm{L})$

$\mathrm{CL}=$ konsentrasi $\mathrm{NH}_{4} \mathrm{OH}$ dalam cairan $(\mathrm{mg} / \mathrm{L})$

$\mathrm{Co}=$ konsentrasi $\mathrm{NH}_{4} \mathrm{OH}$ dalam cairan mula-mula $(\mathrm{mg} / \mathrm{L})$

$\mathrm{K}=$ konstanta Persamaan Langmuir/Freundlich

$\mathrm{n}=$ konstanta persamaan Freundlich 


$$
\begin{aligned}
\mathrm{W}= & \text { berat zeolit }(\text { gram }) \\
\mathrm{V}= & \text { volume larutan } \mathrm{NH}_{4} \mathrm{OH}(\mathrm{mL} \\
\mathrm{Xe}= & \text { konsentrasi } \mathrm{NH}_{4} \mathrm{OH} \text { dalam padatan pada saat } \\
& \text { kesetimbangan }(\mathrm{mg} / \mathrm{gr} \text { zeolit })
\end{aligned}
$$

\section{Daftar pustaka}

Auerbach, S., Carrado, K., and Dutta, P.K., 2003, "Handbook of Zeolite Science and Technology", Marcel Dekker, Inc., New York.

Ding, Y., Sartaj, M., 2015, Statistical analysis and optimization of ammonia removal from aqueous solution by zeolite using factorial design and response surface methodology, Journal of Environmental Chemical Engineering, 3, 807-814.

Kirk, R.E. and Othmer, D.E,1951, "Encyclopedia of Chemical Technology, vol.5, pp.781-790, Interscience Incyclopedia Inc., New York.

Lin, L., Lei, Z., Wang, L., Liu, X., Zhang, Y., Wan, C., Lee, D.J., Tay, J.H., 2013, Adsorption mechanisms of high-levels of ammonium onto natural and $\mathrm{NaCl}$ modified zeolites, Separation and Purification Technology, 103, 15-20.

Lusiana, O., 2008, "Pemanfaatan Zeolit Alam Sebagai Adsorben Dan Katalis Yang Bersifat Asam", Jurusan Teknik Kimia, Fakultas Teknik, UGM, Yogyakarta.

Perry, R.H., and Green, D.W., 1997, "Perry's Chemical Enginers Handbook", 7ed., pp. 16-8 - 16-15, McGraw Hill Book Company, Inc., New York.

Saltali, K., Sari, A., and Aydin, M., 2007, "Removal of ammonium ion from aqueous solution by natural Turkish (Yıldizeli) zeolite for environmental quality", Journal of Hazardous Materials., 141, 258-263.

Treybal, R.E., 1981, "Mass Transfer Operation", 3ed., pp. 106-110, McGrawHill Book Comapny, Inc., New York

Veselovskaya, J.V., Tokarev, M.M., Grekova, A.D., Gordeeva, L.G., 2012, Novel ammonia sorbents "porous matrix modified by active salt" for adsorptive heat transformation: 6. The ways of adsorption dynamics enhancement, Applied Thermal Engineering, 37, 87-94.

Wang, Y.F., Lin, F.,Pang, W.Q., 2007, “Ammonium exchange in aqueous solution using Chinese natural clinoptilolite and modified zeolite", Journal of Hazardous Materials., 142, 160-164. 